\title{
MOTIVATION FACTORS FOR REZEKNE MUNICIPALITY ENTREPRENEURS TO ENGAGE IN MENTORING ACTIVITIES
}

\author{
Anda Zvaigzne ${ }^{1}$, Dr.oec.; Inta Kotane'2, Mg.oec.; Daina Znotina ${ }^{3}$, Mg. soc.sc. and Inita \\ Krivasonoka ${ }^{4}$, Mg.oec. \\ ${ }_{1,2,3}$ Research Institute for Business and Social Processes, Faculty of Economics and Business Management, \\ Rezekne Academy of Technologies; ${ }^{4}$ Latvian Rural Advisory and Training Centre
}

\begin{abstract}
In recent years, the role of mentoring in entrepreneurship is increasingly discussed by scientists and the public. The research aim is to identify and analyse motivational factors for entrepreneurs in Rezekne municipality to engage in mentoring activities. The theoretical literature review done by the authors shows that mentoring refers to relationships and communication that involve sharing experience and support provided by an individual who shares his/her knowledge, experience and wisdom to another individual - a mentee - who is ready and who has a wish to benefit from the exchange and to improve his/her professionalism. The research results revealed that in Rezekne municipality, entrepreneurs were motivated to get new contacts and cooperation partners and have an opportunity to do a job benefiting the entire society. However, mentees were motivated by an opportunity to learn and increase their self-confidence and a wish to successfully start up a business. The survey done by the authors revealed that mentoring in entrepreneurship in Rezekne municipality could contribute to the development of unexperienced enterprises. Mutual communication between potential mentors and mentees would avoid a lack of information and advice, and sharing experience would develop their initiative. Accordingly, it is necessary to continue the research started by the authors by establishing a database for and identifying potential mentors and mentees in the other municipalities of Latgale region who can and are ready to engage in the business mentor network.
\end{abstract}

Key words: mentoring, mentor, motivational factors, mentee.

JEL code: A00; L26.

\section{Introduction}

Steady economic growth in the regions of the country plays an important role in the growth of the national economy. Reports, research investigations and publications by the Ministry of Economics of the Republic of Latvia, the State Regional Development Agency and the Bank of Latvia indicate that disparities in income, employment opportunities and output between the central part of Latvia and the other part of the country, particularly Latgale region and southwestern Kurzeme, continue increasing (Ekonomikas ministrija, 2017).

To reduce territorial disparities, the government produced the Regional Policy Guidelines for 20132019 that are, to some extent, a continuation of the Action Plan for Growth in Latgale Region 20152017 (VARAM, 2017). Both documents envisage the improvement of transport infrastructures to reach development centres and financial and technical assistance for entrepreneurship, the revitalisation of degraded areas and other activities throughout Latvia and Latgale region in particular. However, as pointed out by the Ministry of Economics, to achieve faster growth in Latgale, it is necessary to focus on the development centres of the region by promoting the attraction of foreign investments and the transfer of technologies as well as the development of industrial areas and human resources (Ekonomikas ministrija, 2017).

Researcher R.Zvirgzdina who examined business development in the rural areas of Latvia believes that fostering economic activities in the rural areas requires a comprehensive approach, which would involve retraining the rural population and creating opportunities for acquiring basic knowledge of business, general economic knowledge and advice (Zvirgzdina R., 2006). Other researchers who

\footnotetext{
1 anda.zvaigzne@rta.Iv

2 inta.kotane@rta.Iv

3 daina.znotina@rta.Iv

4 inita.krivasonoka@llkc.Iv
} 
examined the entrepreneurial environment in the regions (LU, 2010; LIAA, 2009; Altum, 2017) referred to the need to apply experience transfer techniques. Such an opportunity is provided by mentoring whereby experienced mentors transfer their knowledge to mentees. Mentoring is based on the knowledge and experience of a mentor that allows a mentee to consider his/her disposable options and resources and encourages the mentee to use them to solve some problem or achieve a goal (Konstantinova E., Rivza B., 2007).

According to Lursoft data, the number of liquidated enterprises considerably rose in 2018 (Lursoft, 2019). The problems of the failed enterprises were diverse, yet the key problems, particularly for new enterprises, were as follows: 1 . lack (inaccessibility) of funds; 2 . lack of knowledge and experience;

3. lack of connections and contacts in the relevant business field (Biedriba "Lietisko sieviesu apvieniba", 2012). There are still No unified and complex solutions to meet all the needs in the field of transfer of knowledge and experience in all the regions of Latvia.

The research hypothesis is as follows: it is impossible to determine the motivational factors for entrepreneurs in Rezekne municipality to engage in mentoring activities.

The research aim is to identify and analyse the motivational factors for entrepreneurs in Rezekne municipality to engage in mentoring activities.

To achieve the aim, the following specific research tasks are set:1.to examine the theoretical aspects of mentoring; 2.to assess the results of a survey of mentors and mentees in Rezekne municipality.

Research methods employed: monographic and descriptive; analysis and synthesis, statistical analysis and sociological methods - surveying and interviewing.

The research conducted a survey of mentors (entrepreneurs) and mentees with the aim of collecting information and data on entrepreneurs wishing to participate in business mentor network activities in Rezekne municipality. Questionnaires were sent electronically, enterprise managers were spoken to in person and interviewed via phone as well as the questionnaires were published on the Facebook page of the Rezekne municipality local government. Two kinds of questionnaire were disseminated, appealing to current entrepreneurs being ready to become mentors as well as future entrepreneurs wishing to learn and get inspired by experienced entrepreneurs. This study was conducted from November 2018 to January 2019.

The research used the specific literature on mentoring and business development, the legal frameworks and policy documents of the Republic of Latvia and the EU, publications and other sources, relevant research papers of national and foreign scientists as well as industry specialist articles on the given topic.

\section{Research results and discussion}

\section{Theoretical aspects of mentoring}

In recent years, mentoring as a kind of knowledge transfer became increasingly popular and widespread in Latvia. This means that a person (mentor) having experience in a relevant field transfers the experience to a person (mentee) having No such experience or having little experience.

The origins of mentoring are found in Japan, England, Sweden and the USA, yet mentoring soon became popular in the other European countries as well. The way mentoring is used slightly differs in each country. In North America, mentoring is mainly used for career growth, and the mentor is responsible for building up skills and talents in the mentee and for the mentee's career growth, while 
in European mentoring the mentor helps the mentee to enhance the skills and make success him/herself (LIAA, 2009).

In Europe, mentoring takes various forms, it has adapted to various purposes and needs and found diverse uses.

Effective business mentoring is based on the mentor's knowledge of and experience in business and communicative skills as well as the encouragement of the mentee in a friendly and positive way (LIAA, 2012). Mentoring is an effective knowledge transfer process that came to Latvia owing to assistance provided by the European Commission; it is implemented by experienced mentors working with their mentees (Konstantinova E., Rivza B., 2007). Researcher Stern, however, points out that the history of mentoring as a knowledge transfer process is long. In Latvia, this approach has been employed since the $14^{\text {th }}$ century - masters from various fields taught their apprentices who later became masters themselves, transferring their skills to others (Sterns I., 1997).

Scientist R.Sullivan stresses the strong relationship between the mentor and the mentee that creates a safe environment for the growth and development of the mentee (Sullivan R., 2000). This opinion is supported by researchers who emphasise that the mentor has to be sensitive to the emotional and intellectual world of the mentee. Sensitivity is the basis for trust in relations between mentoring participants and better conditions for learning. This perspective of mentoring is typical of mostly psychology and education researchers (Konstantinova E., 2008).

Researcher E.A.Ensher defines mentoring as „....prudent formation of pairs of persons with different experience and skills with the aim of contributing to the growth of, and building up specific skills in less experienced persons..." (Ensher E.A. et al., 2002). According to researchers D.Clutterbuck and D.Meginson, the mentor becomes a trusted person and, giving assistance, achieves considerable change in the mentee's knowledge, work and thinking (Clutterbuck D. et al., 2005).

Mentoring could be characterised as bilateral "communicative relations" that consist of verbal and nonverbal behaviour and whose goal is to offer or request assistance. Performing this dialogue communication, mentors develop and give relevant messages that are referred to as a specific communicative behaviour or one party's action aimed at benefitting someone or helping others (Burleson B. et al., 2002). This implies mentors have to regularly adapt their communication in order to understand the needs of the other party; therefore, both parties need an understanding of their communication style and a wish to objectively assess the behaviour of the person assisted (Radu Lefebvre M., Redien-Collot R., 2013).

The literature review of mentoring has revealed that gender effects on mentoring programmes are extensively analysed and researched. In the world, most of the mentors are men, as the men are those who take leading job positions at many companies. It has been found that mentors play a great role in men's career growth and even a greater role in women's career growth (Burke R.J. et al., 1994). As found in research studies, both male and female mentees confirmed that they were more satisfied with the mentors who provided psychological support for their career growth. It was found that the relations between the mentor and the mentee could range from excellent to very unsatisfactory (LIAA, 2009). This allows concluding that mentors themselves do not guarantee growth, yet the quality of growth depends on the relations between the mentor and the mentee or more precisely, consistency between the mentee's needs and the mentor's ability to support the needs (LIAA, 2009). 
The authors' theoretical literature review indicates that mentoring refers to relationships and communication that involve sharing experience and support provided by an individual who shares his/her knowledge, experience and wisdom to another individual - a mentee - who is ready and who has a wish to benefit from the exchange and to improve his/her professionalism. Since mentoring requires the mentor to go deep into in the mentee's problems and the matters to be discussed, the mentor does not teach but encourages the mentee him/herself to make a decision.

Further, the authors analyse the results of a survey of mentors and mentees in Rezekne municipality.

\section{Results of the survey of mentors and mentees in Rezekne municipality}

The quantitative survey of entrepreneurs was conducted from November 2018 to January 2019. Among the respondents, women represented $18.2 \%$ and men $81.8 \%$; the highest percentage (36.4 \%) was found for the group aged 41-45 who had a Bachelor's degree or second-level professional higher education (36.4\%) in natural sciences (36.5\%). Among the mentees, $52.6 \%$ were women and $47.4 \%$ were men; the highest percentage (31.6\%) was observed for the group aged 26-30 who had a Bachelor's degree or second-level professional higher education in social sciences $(36.5 \%)$.

The surveyed enterprises engaged in mentoring were divided into three categories: 1. microenterprises (0-5 employees) - $72.7 \%$ of the total respondents; 2 . small enterprises (6-10 employees) $-18.2 \%$ of the total respondents; 3 . medium enterprises (31-40 employees) $-9.1 \%$ of the total respondents.

The participation activity of entrepreneurs (mentors) in the survey was low in Rezekne municipality. Only 11 questionnaires were received back from entrepreneurs (mentors) and 19 from future or new entrepreneurs (mentees).

Based on the information available in public databases and on the Internet, 98 enterprises registered in Rezekne municipality (Table 1) were selected; the enterprises were sent an invitation to participate in the online survey conducted by use of the indirect surveying method (information on the survey was sent to the potential respondents via email, requesting them to fill in a questionnaire electronically on the portal google.com. The invitation was sent twice - in the beginning of November 2018 and in December (the second one was a reminder about the participation in the survey). In view of the low activity of entrepreneurs, the authors made a decision to do interviews by phone, speaking to every potential respondent in person and filing in questionnaires themselves.

Table 1

Characteristics of the sample reached

\begin{tabular}{|l|c|}
\hline \multicolumn{1}{|c|}{ Kind of study } & Number \\
\hline $\begin{array}{l}\text { Number of email addresses that were sent an invitation to participate in } \\
\text { the survey }\end{array}$ & 98 \\
\hline Number of completed web questionnaires & 12 \\
\hline Telephone - the number of interviews & 25 \\
\hline Size of the sample & 37 \\
\hline Number of valid and processed questionnaires & 30 \\
\hline
\end{tabular}
Source: authors' study

To reach a larger number of potential mentees, which could be also represented by entrepreneurs who are establishing their own enterprise or only plan to do it and their contact information is not available publicly, the authors used an opportunity to publish the questionnaires on the Facebook page of the Rezekne municipality local government. 
A questionnaire was filled in for every entrepreneur individually (or it was done by the entrepreneur him/herself). The research group tested the questionnaires received for validity. The questionnaires meeting the quality standards were prepared for data processing and summarisation.

Among the respondents - Rezekne municipality entrepreneurs (mentors) - , the highest percentage was found for those representing enterprises engaged in agriculture, forestry and fisheries, wholesale and retail trade and repair of motor vehicles and motor cycles (27.3\%). Of the respondents, $36.4 \%$ indicated that earlier they worked in another enterprise engaged in the same field of economic activity; $90.9 \%$ noted that besides entrepreneurship they had experience in other fields, the duration of their enterprises was 6-10 years $(45.5 \%)$ and the average number of employees was 0-5 (72.7\%).

As regards the mentees, the highest percentage was found for those representing enterprises engaged in agriculture, forestry and fisheries as well as accommodation and food service activities (21.1 \%). Of the respondents, $42.1 \%$ indicated their enterprises were in the process of establishment.

To identify the factors motivating Rezekne municipality entrepreneurs - potential mentors - to engage in the mentoring network, a question was asked, "What factors motivate you to engage/work in business mentor network activities as a mentor" $(n=11)$ ?" (Table 2$)$.

Table 2

Factors motivating individuals to engage in business mentor network activities as a mentor, $(\mathbf{n = 1 1})$ (respondents could choose several reply options)

\begin{tabular}{|c|c|c|c|}
\hline \multirow[b]{2}{*}{ Factors } & \multicolumn{2}{|c|}{ Replies } & \multirow{2}{*}{$\begin{array}{c}\text { Occurrence } \\
\text { frequency, } \\
\%\end{array}$} \\
\hline & Number & $\begin{array}{l}\% \text { of } \\
\text { total }\end{array}$ & \\
\hline Opportunity to do a job benefitting the entire society & 4 & 22,2 & 36,4 \\
\hline $\begin{array}{l}\text { Opportunity to help others to successfully start up a } \\
\text { business }\end{array}$ & 3 & 16,7 & 27,3 \\
\hline Opportunity to get new contacts/cooperation partners & 6 & 33,3 & 54,5 \\
\hline $\begin{array}{l}\text { Opportunity to contribute to self-development and self- } \\
\text { confidence }\end{array}$ & 3 & 16,7 & 27,3 \\
\hline Others & 2 & 11,1 & 18,2 \\
\hline Total: & 18 & 100,0 & 163,6 \\
\hline
\end{tabular}

Dichotomy group tabulated at value 1

Source: authors' study

Of the respondents, $33.3 \%$ referred to "Opportunity to get new contacts/cooperation partners" and $22.2 \%$ - "Opportunity to do a job benefitting the entire society" as important motivational factors. "Opportunity to help others to successfully start up a business" and "Opportunity to contribute to self-development and self-confidence" were also considered important motivational factors by $16.7 \%$ respondents. Those who ticked the reply option "Others" wrote that they would be motivated by guaranteed remuneration or another material benefit.

To identify the factors motivating entrepreneurs - mentees - to engage in the mentoring network, a question was asked, "What factors motivate you to engage/work in business mentor network activities as a mentee?"

Of the respondents, $34.5 \%$ considered "Opportunity to learn and get confidence in one's own abilities" an important motivational factor, while $24.1 \%$ would be motivated by the "Wish to successfully start up a business" and $20.7 \%$ - by the "Opportunity to get new contacts/cooperation partners". A relatively low percentage, $6.9 \%$, of the respondents saw No motivation to engage in the mentoring network (Table 3). 
Factors motivating individuals to engage in business mentor network activities as a mentee, $(\mathbf{n}=\mathbf{1 9})$ (respondents could choose several reply options)

\begin{tabular}{|c|c|c|c|}
\hline \multirow[b]{2}{*}{ Factors $^{a}$} & \multicolumn{2}{|c|}{ Replies } & \multirow[b]{2}{*}{$\begin{array}{l}\text { Occurrence } \\
\text { frequency, } \%\end{array}$} \\
\hline & Number & $\begin{array}{l}\text { \% of } \\
\text { total }\end{array}$ & \\
\hline Get advice on/a solution to business problems & 4 & 13.8 & 21.1 \\
\hline Wish to successfully start up a business & 7 & 24.1 & 36.8 \\
\hline Opportunity to get new contacts/cooperation partners & 6 & 20.7 & 31.6 \\
\hline $\begin{array}{l}\text { Opportunity to learn and get confidence in one's own } \\
\text { abilities }\end{array}$ & 10 & 34.5 & 52.6 \\
\hline No motivation & 2 & 6.9 & 10.5 \\
\hline Total: & 29 & 100.0 & 152.6 \\
\hline
\end{tabular}

${ }^{a}$ Dichotomy group tabulated at value 1

Source: authors' study

The survey data revealed that most respondents - both potential mentors and mentees considered purposefulness and persistence to be the most important personality traits contributing to success in entrepreneurship, $24.4 \%$ and $21.4 \%$ of the total replies, respectively (Table 4 ). The potential mentors also referred to diligence, love for work and knowledge and education. The mentees recognised diligence, love for work and the sense of responsibility and duty as equally important. The mentors, choosing the reply option "Others" (9.8\% of the total replies), indicated the following: foreign language skills, optimism and employee management. The mentees (7.1\% of the total replies), however, specified that the heart had to be put in work, success was needed or you had to be at the right place and time, contacts were needed, and not only knowledge and experience.

Personality traits contributing to success in business and management, \% (respondents could choose several reply options)

\begin{tabular}{|l|c|c|}
\hline \multicolumn{1}{|c|}{ Traits } & $\begin{array}{c}\text { Mentors } \\
(\mathbf{n = 1 1 )}\end{array}$ & $\begin{array}{c}\text { mentees } \\
(\mathbf{n = 1 9 )}\end{array}$ \\
\hline Purposefulness and persistence & 24.4 & 21.4 \\
\hline Communicative skills & 9.8 & 12.5 \\
\hline Knowledge and education & 14.6 & 12.5 \\
\hline Diligence, love for work & 19.5 & 16.1 \\
\hline Sense of responsibility and duty & 4.9 & 16.1 \\
\hline Flexibility, adaptation & 9.8 & 5.4 \\
\hline Tendency to risk & 7.3 & 8.9 \\
\hline Others & 9.8 & 7.1 \\
\hline
\end{tabular}

Source: authors' study

The potential mentors, assessing hardships and problems they had faced when starting up their businesses, noted a lack of capital and funds and a lack of information/advice as the most important factors. A lack of contacts and cooperation, difficulty in combining family life and work, a lack of a workforce and problems with selling the product were equally assessed by them.

The mentees, assessing the most considerable barriers to entrepreneurship, recognised a lack of funds, a lack of resources and relevant experience and a lack of initiative as the most important ones. Besides, $17.6 \%$ of them hoped that they would attract more investment and funds for their enterprises by means of a mentor. The survey results confirmed the necessity for a business mentor network, as well as the need for financial support instruments for entrepreneurs. 
The survey results revealed that neither the mentor's age and gender nor his/her job position were important to the mentees, while the mentor had to possess the following traits of character: esteem, leadership, honesty and talent.

The authors' research indicates that mentoring in entrepreneurship could contribute to the development of unexperienced enterprises in Rezekne municipality. Bilateral communication between potential mentors and mentees would avoid a lack of information and advice, and sharing experience would contribute to their initiative. Therefore, it is necessary to continue the research started by the authors by establishing a database for and identifying potential mentors and mentees in the other municipalities of Latgale region who can and are ready to engage in the business mentor network.

\section{Conclusions}

1) Mentoring is one of the most effective ways of how to transfer experience among enterprises by actively sharing knowledge, experience and contacts. Mentoring in entrepreneurship is mainly used for developing new and unexperienced enterprises.

2) In Rezekne municipality, entrepreneurs are motivated to become mentors by an opportunity to get new contacts/cooperation partners and to do a job benefitting the entire society. Mentees, however, are motivated by an opportunity to learn and get confidence in one's own abilities and a wish to successfully start up a business.

3) The hypothesis put forward by the research did not prove to be true, and, the authors believe, continuing the research would clearly identify the motivational factors.

4) The survey revealed that most respondents - both potential mentors and mentees - considered purposefulness and persistence to be the most important personality traits contributing to success in entrepreneurship. The potential mentors also referred to diligence, love for work and knowledge and education. The mentees, however, recognised diligence, love for work and the sense of responsibility and duty as equally important.

5) It is necessary to continue the research started by the authors by establishing a database for and identifying potential mentors and mentees in the other municipalities of Latgale region who can and are ready to engage in the business mentor network.

6) The authors believe that the local government of Rezekne municipality and advisors in entrepreneurship should promote the dissemination of information about business opportunities, ideas and experience as well as business success stories, as the survey revealed that mentees would appreciate an opportunity to learn from mentors - experienced entrepreneurs.

\section{RT}

The paper was produced with the financial support of Rezekne Academy of Technologies from the research grant "Mentoring Opportunities for Entrepreneurship Development in Rezekne Municipality".

\section{Bibliography}

1. Attistibas finansu institucija Altum (2017). ALTUM petijums: Iesaistoties uznemejdarbiba, uzlabojas apmierinatiba ar dzivi un finansiala situacija (Development Finance Institution Altum. Altum Study: Engagement in Business Enhances Satisfaction with the Life and the Financial Position). Retrieved: https://www.altum.Iv/lv/jaunumi/-altum-petijums-iesaistoties-uznemejdarbiba-uzlabojas-apmierinatiba-ardzivi-un-finansiala-situacija. Access: 24.10.2018.

2. Biedriba "Lietisko sieviesu apvieniba" (2012) Lietisko sieviesu apvienibas administrativas kapacitates celsana. Mentoringa programma (Business Women Association. Increasing the Administrative Capacity of the Business Women Association). Retrieved:

http://www.sif.gov.Iv/nodevumi/nodevumi/4949/mentoringa_programma.pdf. Access: 26.10.2018.

3. Burke, R.J., McKeen, C.A., McKenna, C. (1994). Benefits of Mentoring in Organizations: The Mentor's Perspective. Retrieved: https://www.emeraldinsight.com/doi/abs/10.1108/02683949410062556. Access: 30.10.2018. 
4. Burleson, B., MacGeorge, E., Knapp, M., \& Daly, J. (2002). Supportive Communication. Handbook of Interpersonal Communication (3rd ed., pp. 374-424). London, England: SAGE.

5. Clutterbuck, D., Megginson, D., Garvey, B., Stokes, P., Garrett-Harris, R. (2005). Mentoring in Action, 2nd ed. London: Kogan Page. 288 p.

6. Ensher, E.A., Murpfy, S.E., Vance. C.M. (2002). Mentoring and Self-management Career Strategies for Entrepreneurs. International Journal of Entrepreneurship and Innovation, vol.1, No.2, pp.99-108.

7. Konstantinova E., Rivza, B. (2007). Mentoringa rokasgramata. Metodiskais materials. LLU sadarbiba ar Interreg III B projektu FEM (Mentoring Handbook. Methodological Material. LLU in cooperation with Interreg III B project FEM (Female. Entrepreneurs' Meetings in the Baltic Sea Region)), Jelgava.

8. Konstantinova, E. (2008). Mentorings ka zinasanu parneses process uznemejdarbibas veicinasanai Latvijas laukos. Promocijas darbs ekonomikas doktora (Dr.oec.) zinatniska grada iegasanai (Mentoring as Knowledge Transfer Process for Promoting Entrepreneurship in Rural Ares of Latvia. Dissertation for the scientific degree of Dr.oec.), LLU.

9. Latvijas Investiciju un attistības agentura (2009). Labas prakses piemeri mentoringa (Best Practice Examples in Mentoring). Retrieved:

www.liaa.gov.Iv/files/liaa/attachments/16_labas_prakses_piemeri_mentoringa.pdf. Access: 24.10.2018.

10. Latvijas Investiciju un attistības agentura (2012). Biznesa mentoru tikla rokasgramata mentoriem un pieredzes parnemejiem (Investment and Development Agency of Latvia. Business Mentor Network Handbook for Mentors and Mentees). Retrieved: http://new.Ilkc.Iv/sites/default/files/baskik_p/pielikumi/mentorings-vadlinijas.pdf Access: 03.09.2018.

11. Latvijas Universitate. (2010). Mentoru rokasgramata (University of Latvia. Mentor's Handbook). Retrieved: https://skolas.lu.lv/mod/resource/view.php?id=20582. Access: 24.10.2018.

12. LR Ekonomikas ministrija (2017). Aseradens: regionu attistibas sekmesana ir Latvijas ekonomikas straujakas izaugsmes avots (Ministry of Economics of the Republic of Latvia. Aseradens: Promoting Regional Development is a Source of Faster Economic Growth in Latvia). Retrieved: https://em.gov.Iv/lv/jaunumi/14899-aseradens-regionu-attistibas-sekmesana-ir-latvijas-ekonomikasstraujakas-izaugsmes-avots Access: 01.10.2018.

13. Lursoft (2019). 2018.gada jauns likvideto uznemumu skaita rekords (2019) (New Record of the Number of Liquidated Enterprises in 2018). Retrieved: http://blog.lursoft.lv/2019/01/02/2018-gada-jauns-likvidetouznemumu-skaita-rekords/ Access: 10.01.2019.

14. Radu Lefebvre, M., Redien-Collot, R. (2013). "How to do Things with Words”: The discursive dimension of experiential learning in entrepreneurial mentoring dyads. Journal of Small Business Management, 51, pp.370-393.

15.Sullivan, R. (2000). Entrepreneurial Learning and Mentoring. International Journal of Entrepreneurial Behaviour and Research, vol.6, No.3, pp.160-175.

16. Sterns, I. (1997). Latvijas vesture 1290-1500 (History of Latvia 1290-1500). Daugava, Riga. 478 p.

17. Vides aizsardzibas un regionalas attistibas ministrijas darbibas strategija 2017. - 2019.gadam (2017) (Operational Strategy for the Ministry of Environmental Protection and Regional Development for 20172019). Riga, 50 p.

18. Zvirgzdina, R. (2006). Uznemejdarbibas aktivizesana lauku regionos globalizacijas konteksta (Enterprises Activated in Country Regions in Global Context), Economic Science for Rural Development, No. 10, pp. 227233. 